\title{
Short Communication: Antagonistic activity of bacteria isolated from coral Acropora sp of Karimunjawa Islands, Indonesia against Acroporid White Syndrome
}

\author{
AGUS SABDONO ${ }^{1, \bullet}$, AGUS TRIANTO ${ }^{2}$, OCKY KARNA RADJASA ${ }^{1}$, DIAH PERMATA WIJAYANTI ${ }^{2}$ \\ ${ }^{1}$ Program of Marine Science, School of Graduates, Universitas Diponegoro. Jl. Prof. H. Soedarto, S.H., Tembalang, Semarang 50275, Central Java, \\ Indonesia. Tel.: +62-24-7474698, Fax.: +62-24-7474698, `email: agus_sabdono@yahoo.com. \\ ${ }^{2}$ Department of Marine Science, Faculty of Fisheries and Marine Science, Universitas Diponegoro. Jl. Prof. H. Soedarto, S.H., Tembalang, Semarang \\ 50275, Central Java, Indonesia
}

Manuscript received: 2 February 2019. Revision accepted: 25 April 2019

\begin{abstract}
Sabdono A, Trianto A, Radjasa OK, Wijayanti DP. 2019. Antagonistic activity of bacteria isolated from coral Acropora sp of Karimunjawa Islands, Indonesia against Acroporid White Syndrome. Biodiversitas 20: 1350-1355. Acroporid White Syndrome (AWS) disease, causing coral death and mortality, has come out as a serious threat to coral reefs in the Karimunjawa Islands, Java Sea. In the present study, the bacterial community associated with the Acroporid were assessed for their antagonistic activity against bacteria associated with AWS disease. A culture collection of 43 bacteria associated with coral Acroporid was established by plating on Zobell's 2214E. Isolates were screened using the overlay method. The results showed that five isolates (11.62 \%) were able to inhibit the growth of the AWS isolates. These isolates were tested further for their consistency of antagonistic activity by using disc-agar diffused method. Based on their consistency, AU5 isolate was selected for study at advance. Polyphasic and phylogenetic analysis were used to characterized AU5 isolate. The DNA sequence analyses demonstrated that this bacterial isolate affiliated with Firmicutes. The AU5 isolate showed high 16S rDNA sequence identity to Virgibacillus salarius strain muzPC213 (99\%). The results demonstrated the existence of bacterial coral symbionts with AWS antipathogenic activity on the coral tissue, possibly performing as biocontrol agent to protect the coral Acroporids against AWS outbreaks.
\end{abstract}

Keywords: Acropora, acroporid white syndrome, coral bacteria, Karimunjawa, polyphasic

\section{INTRODUCTION}

Coral bleaching and associated mortality have negative impacts on the abundance and diversity of coral and fish communities (Casey et al. 2014; Komyakova et al. 2018). Changes in coral community composition can occur when more susceptible species are killed by disease outbreak events. Declines in genetic and species diversity may occur when corals die (Baskett et al. 2009; Baker et al. 2008). However, the direct impact of coral disease on coral reef biodiversity is still unclear (Rogers 2013; Richards and Day 2018). Bruno et al. (2007) stated that the outbreak of coral disease contributed to the decline of coral cover. Also, Miller et al. (2009) and Roff and Mumby (2012) stated that diseases have an important role in the declines of the diversity and resilience of coral reef communities. Several previous studies reported that the Acroporid White Syndrome (AWS) was related to tissue loss in the forms of irregular bands or patches of the white skeleton in the IndoPacific (Willis et al. 2004; Raymundo et al. 2008; Sussman et al. 2008; Yamashiro et al. 2016). While Aronson and Precht (2001) stated that AWS is the main factor in coral degradation in the Caribbean Sea.

Coral reefs are one among several ecosystems that exist dominantly in Karimunjawa National Park (Campbell et al. 2013; Susanto et al. 2014). Branching coral Acropora sp. grows abundantly in some islands of the Park. However, most of them were attacked by AWS (Sabdono et al. 2019).
Although members of the Acroporidae display many colony growth forms on these reefs (personal field observation), the outbreak of AWS discovered in 2016 mainly affected tabular Acroporids (Figure 1). Obvious signs of AWS were recognized around Karimunjawa Park. This disease is mainly distributing to the dominant species of tabular Acroporid corals in Kemujan, Sintok, and Cendekian islands (Figure 2).

The AWS disease is etiologically known by the rapid damage to the surface tissue of the reef. Then it is followed by sloughing the tissue so that the white skeleton tissues appear a greenish because of algae colonization. The growth of endolytic algae causes the discoloration of the skeleton (Green and Bruckner 2000). Roff et al. (2006) reported that the rate of lesion acceleration in coral colonies varied greatly. Although the etiology of AWS is very little known, lesion borders can be recognized by the limitation of microbial communities.

In recent times, the antipathogenic microorganism was used for biocontrol agents in agricultural crop pathogen (Elkahoui et al. 2014) and aquaculture (Kesarcodi-Watson et al. 2008). In corals, there are no known procedures on how to prevent and control coral diseases. Several approaches have been attempted to stop and to mitigate coral disease outbreaks. Raymundo et al. (2008) removed black band bacterial mats from lesions and then covered the lesion with epoxy. Efrony et al. (2007) used phage therapy method to reduce the spread of coral disease. However, these methods have not been any success. 


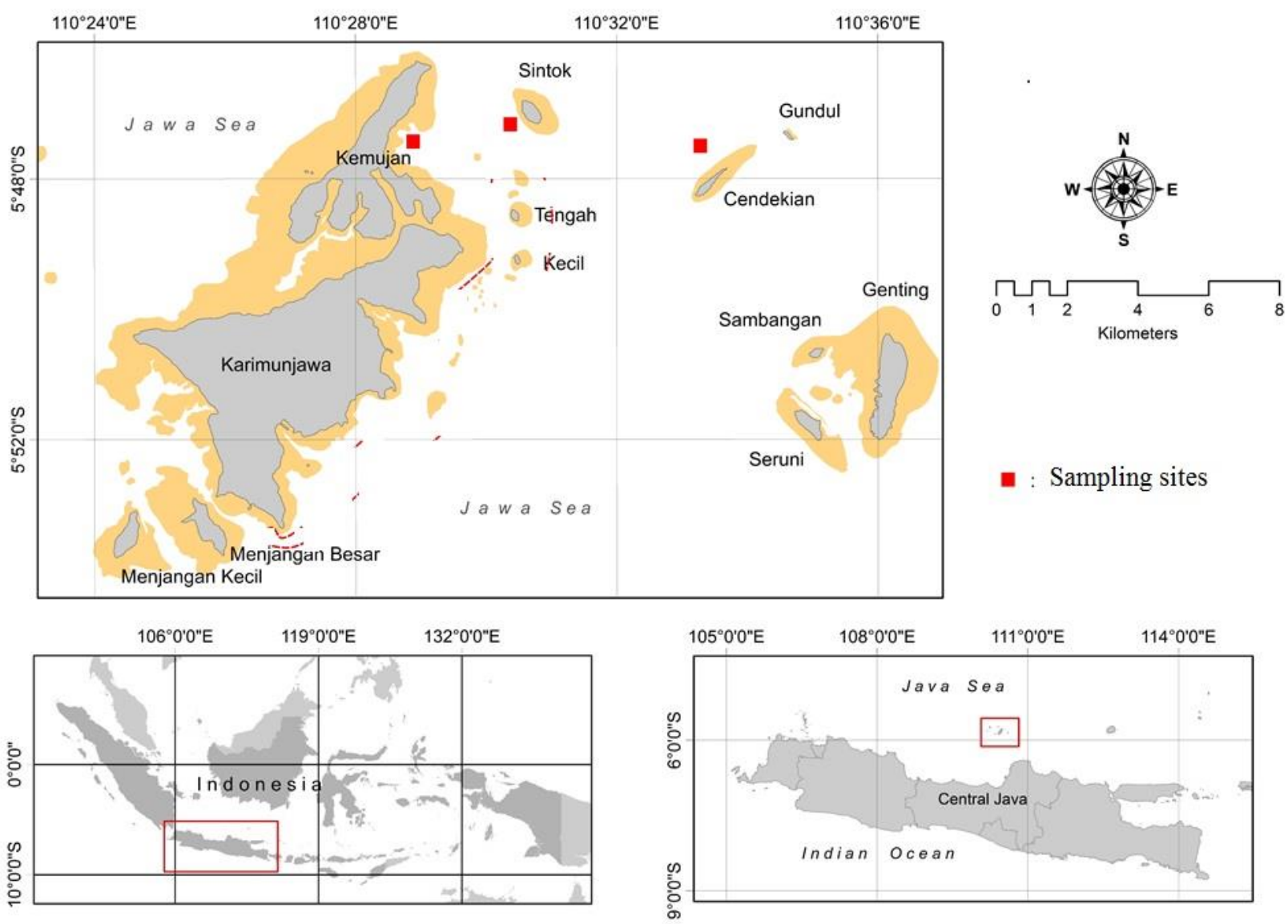

Figure 2. Sampling site locations of Karimunjawa Islands, Java Sea, Central Java, Indonesia

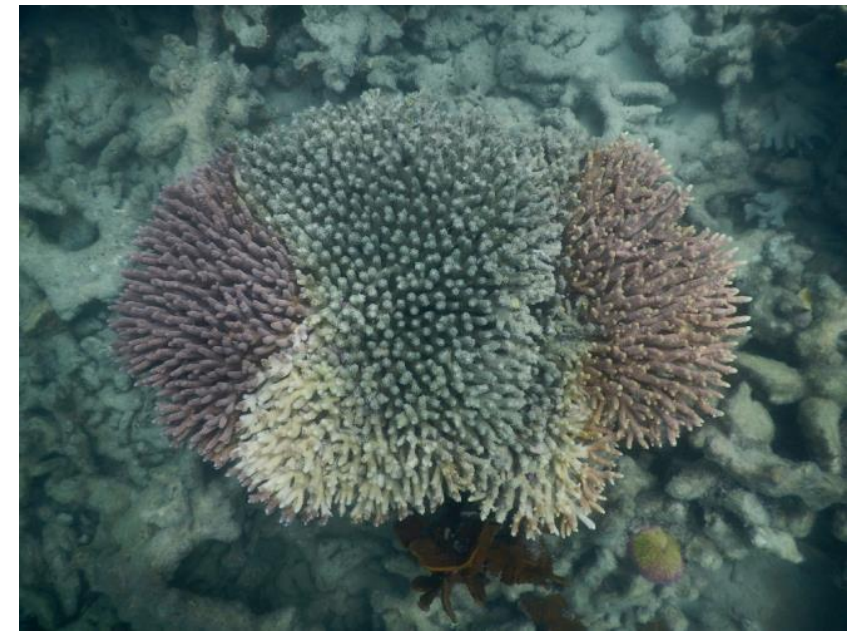

Figure 1. Acroporid white syndrome in Karimunjawa islands, Java Sea, Central Java, Indonesia

Ritchie (2006) and Shnit-Orland et al. (2009) reported that native coral-associated bacteria produce antimicrobials capable of inhibiting pathogens. Furthermore, Teplitski and Ritchie (2009) stated the opportunity for exploring these properties in implementing biological control of coral diseases. So, the search of indigenous coral bacterial strains with anti-pathogenic AWS is urgently to be conducted. Hence, the present investigation was undertaken to isolate bacteria associated with the coral reef (Acropora sp) for antagonistic effect against AWS pathogens. The result of this study will help the researchers to uncover the critical areas in the prevention, control and reduce of AWS outbreaks that many researchers were not able to explore. A new strategy on molecular epidemiology and disease control technology of coral diseases in Karimunjawa National Park may arrive at the solution.

\section{MATERIALS AND METHODS}

\section{Coral sampling}

Samples of healthy and AWS coral Acroporid. were carried out on Kemujan, Sintok and Cendekian islands in June 2016. The samples got at 5-8 $\mathrm{m}$ in depth with scuba diving. Then coral fragments (approximately $5 \mathrm{~cm}$ ) were put into Ziploc plastic which had been filled with sterile seawater. Samples were then brought to the laboratory for bacterial isolation. 


\section{Isolation of bacteria from coral samples}

Coral fragments were crushed using sterile mortar and pestle. Then serial dilutions were carried out from a coral paste into $10^{-4}$ up to $10^{-6}$ in sterile seawater. Bacterial isolation was conducted by taking $50 \mu \mathrm{l}$ from each serial dilution and put into the agar marine media. The spread method was used to plant the bacteria. Then the Petri dishes were incubated at room temperature for 48 hours. Colonies were selected based on the morphology colonies (shape, size, texture, and color).

\section{Bacterial isolation and purification}

Isolation and purification of the coral-associated bacteria were carried out using streak method. By morphological features, colonies were randomly picked and purified. The purity of the colony was checked based on morphological and microscopic examination.

\section{Antagonistic activity assay}

Antagonistic activity of the bacteria associated with healthy Acroporid coral was investigated by agar overlay and disc diffusion methods adopted from Radjasa et al. (2007) with slight modification. The overlay test was carried out by growing bacteria associated with AWS on soft agar. Then, these isolates were poured into Zobell 2214E medium that already grown with Acroporid bacterial symbionts that were incubated for 96 hours. The antagonistic activity of Acroporid coral isolates could be determined by the formation of a zone of resistance with a size greater than 1 $\mathrm{mm}$.

\section{Screening antagonistic property}

Antagonistic tests bacterial selected were performed a second time by using the agar disc-diffusion method. Fifty $\mu l$ culture of AWS bacteria in the logarithmic phase were spread on to Zobell 2216 agar medium using glass spreader. Some paper disks were put in the agar surface and then dropped with twenty-five $\mu l$ of each Acroporid coral bacterial culture. The plates were then incubated at room temperature for 48 hours. The appearance of inhibition zones around the paper disc showed the antagonistic activity of isolates and was measured quantitatively.

\section{Phenotypic characterization}

Characteristics of morphology, biochemistry, physiology of the isolates were conducted according to Heyndrickx et al. 1998 and Yoon method (Yoon et al. 2004), such as, gram test, catalase production, growth on acetate, growth on $10 \% \mathrm{NaCl}$, acid production from carbohydrate, acid and gas production from glucose, methyl red and VP assay, NH3 production, indole production.

\section{Molecular identification \\ DNA Extraction and amplification-PCR}

Extraction and partial amplification of $16 \mathrm{~S}$ rDNA from the bacterial strains of AU2 and AU5 were carried out according to the Sabdono and Radjasa method (2008). The primary used was primary forward 8-27: 5'-
AGAGTTTGATCCTGGCTCAG-3 'and reversed the primer 1510-1492: 5'-GGTTACCTTGTTACGACTT-3' (Weisburg et al. 1991; Reysenbach et al. 1992). PCR reactions contained $1 \mu \mathrm{L}$ DNA template (100x diluted), 1 $\mu \mathrm{L}$ primary, $7.5 \mu \mathrm{L}$ Megamix Royal and sterile water up to a total volume of $151 \mu \mathrm{L}$. Amplification was carried out with the Gene Amp PCR System 9700 thermal cyclist model with the following temperature profiles: initial denaturation at $95^{\circ} \mathrm{C}$ for 5 minutes; 30 cycles of denaturation $\left(92^{\circ} \mathrm{C}\right.$ for 1 minute), annealing $\left(50{ }^{\circ} \mathrm{C}\right.$ for 1.5 minutes), extension $\left(68{ }^{\circ} \mathrm{C}\right.$ for 8 minutes $)$, and final extension at $68^{\circ} \mathrm{C}$ for 10 minutes. Five aliquot microliter products PCR were run using electrophoresis on acrylamide gel $6 \%$ using a 1 XTBE buffer.

\section{DNA Sequencing and analysis}

The prospective isolates, as determined by the inhibitory test were identified by using DNA sequencingbased technique. The PCR products were purified with spin columns and prepared using a Sequencing Kit for subsequent sequencing with an automated DNA sequencer. The determined sequences were analyzed by using BLAST for homology test. CLUSTAL X program (Thompson et al. 1994) and aligned manually were also be used for DNA sequencing analyses. The phylogenetic tree was constructed using the PAUP software (available at www.biol.chemie.tu-muenchen.de/pub/arb/). The sequence was submitted to GenBank, and are available under accession numbers LC461005.

\section{RESULTS AND DISCUSSION}

\section{Isolation and screening of antagonistic bacteria}

Results on the overlay test showed that 5 of 43 (11.62 $\%$ ) bacterial isolates of Acropora coral tissues showed the ability to inhibit the growth of AWS bacteria. These bacterial strains have antagonistic activity against at least one bacterial AWS. One of them (AU5 isolate) are intensely active, with antagonistic activity on 3 AWS isolates. These isolates were then reassayed by using agar disc-diffusion method to confirm their consistency to inhibit the AWS isolates (Table 1 and Figure 3). Only one isolate successfully inhibited the growth of 2 AWS isolates after the assay. The AU5 isolate had varying antipathogenic activities against AWS with the range of inhibition zones between 10.20 and $11.07 \mathrm{~mm}$.

Table 1. Screening of antagonistic bacteria used to overlay and agar diffused method in Zobell 2216E plates

\begin{tabular}{lcccc}
\hline \multirow{2}{*}{ Isolate } & \multirow{2}{*}{ Overlay } & \multicolumn{4}{c}{ Agar disc-diffusion $(\mathbf{m m})$} \\
\cline { 3 - 5 } & & AWS1 & AWS2 & AWS3 \\
\hline MU6 & ++ & $10.20 \pm 0$ & - & - \\
AU5 & +++ & $11.07 \pm 0.65$ & - & $10.20 \pm 0$ \\
SM1 & + & - & - & - \\
SM2 & + & 10.40 & - & - \\
CA2 & + & - & - & $10.20 \pm 0$ \\
\hline
\end{tabular}

Note: - : no activity on AWS isolate; + : active only on 1 AWS isolate; ++ : active on 2AWS isolates; +++ : active on 3 AWS isolates 


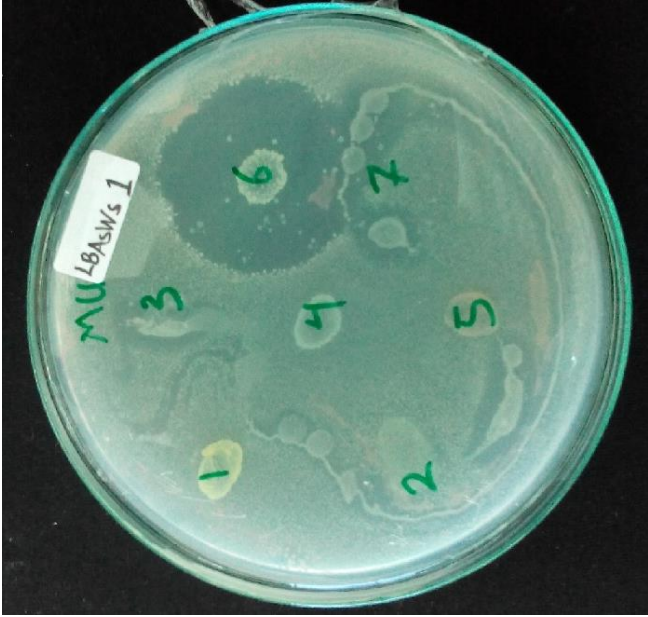

Figure 3: In vitro antagonistic activity of coral bacteria against the pathogenic AWS

Some previous studies on coral bacteria with their properties on antagonistic activity were reported. Wijayanti et al. (2018) screened 87 bacterial strains isolated from corals and tested against Black Band Diseases (BBD) pathogens and found that 14 isolates were active against BBD. Ritchie (2006) demonstrated that 155 of 776 (19.97\%) bacteria associated with mucus from the coral Acropora palmata exhibit antibiotic activity. Shnit-Orland and Kushmaro (2009) showed that 19 among 70 (27.1\%) of bacteria isolated from mucus stony corals displayed antibacterial activity. While Nissimov et al. (2009) reported that 9 out of $156(5.8 \%)$ bacteria isolated from the coral Oculina patagonica inhibited the growth of the coral pathogen Vibrio shiloi. The results suggested that bacteria associated with corals may play a role in the coral defense mechanism through the production of antibacterial compounds.

The reexamined of bacterial activity using agar discdiffusion method showed the decrease of antagonistic activity on several coral isolates. No inhibition zone was formed by SM1 isolate. The decrease of antagonistic activity on this method due to the slow penetration into the medium that affects their ability to inhibit the growth of AWS isolates. Whereas, there was no diffusion problem when overlay method was used. Reller et al. (2009) stated that the disk diffusion method could not be applied to microorganisms that are fastidious, slow growing or have special growth requirements. The AU5 bacterial isolate had a stable and consistent on inhibition of the growth of AWS isolates. Then, this isolate could be used as a candidate for biocontrol agent on AWS disease. Some previous studies reported antagonism of coral-associated bacterial communities that might contribute to pathogenesis as well as disease resistance (Rypien et al. 2009).

\section{Biochemical characterization}

The biochemical characterization results showed that AU5 was gram-positive, a rod-shaped, aerobic bacterium and catalase-positive bacterial isolates. The results also showed that the AU5 coral bacteria could grow at room temperature, did not produce $\mathrm{H}_{2} \mathrm{~S}$, and fermented glucose, cellobiose, galactose, raffinose, and salicin, but not the other sugars tested (Table 2). Phenotypic characteristics of Virgibacillus referred to Heyndrickx et al. (1998) and Yoon et al. (2004). They stated that Virgibacillus are grampositive rods, motile, ellipsoidal endospores in terminal or subterminal, small colonies, irregular circle, yellowish white and almost opaque colors. Phenotypic characteristics of Virgibacillus also referred to Heyndrickx et al. (1998) and Yoon et al. (2004). They stated that Virgibacillus are gram-positive rods, motile, ellipsoidal endospores in terminal or subterminal, small colonies, irregular circle, yellowish white and almost opaque colors. Also, Yoon et al. (2004) added some characteristics such as negative VP, no indole production, nitrate reduction, casein hydrolysis, gelatine and of aesculin positive, and not produced hydrogen sulfide.

Table 2. Microbial characterization of anti-pathogenic AWS coral bacteria

\begin{tabular}{|c|c|c|}
\hline Characters & AU5 & $\begin{array}{c}\text { Virgibacillus sp } \\
\text { (Heyndrickx et al. } \\
\text { 1998) }\end{array}$ \\
\hline Cell shape & rod & rod \\
\hline Gram & + & + \\
\hline Motility & + & + \\
\hline Length cell $>3 \mu \mathrm{m}$ & $+(>3 \mu \mathrm{m})$ & $2-5 \mu \mathrm{m}$ \\
\hline Position and spore shape & - & $\mathrm{T} / \mathrm{ST}$ and $\mathrm{E}$ \\
\hline Spore & - & + \\
\hline Growth on $50^{\circ}$ & $\mathrm{x}$ & $15-500$ \\
\hline Growth on $45^{\circ}$ & $\mathrm{x}$ & $15-500$ \\
\hline Growth with $10 \% \mathrm{NaCl}$ & + & - \\
\hline Anaerobic & - & - \\
\hline Aerobik & + & + \\
\hline \multicolumn{3}{|l|}{ Acid from ASS medium: } \\
\hline - Glucose & + & + \\
\hline - Cellobiose & + & $\mathrm{x}$ \\
\hline - Galactose & + & - \\
\hline - Mannose & - & + \\
\hline - Melibiose & - & - \\
\hline - Raffinose & + & + \\
\hline - Salicin & + & + \\
\hline - Xylose & - & - \\
\hline \multicolumn{3}{|c|}{ Acid from phenol red medium: } \\
\hline - Glucose & + & + \\
\hline - Mannitol & - & - \\
\hline - Sucrose & + & $\mathrm{x}$ \\
\hline - Xylose & + & $\mathrm{x}$ \\
\hline ONPG & $\mathrm{x}$ & + \\
\hline Utilization of Citrate & $\mathrm{x}$ & - \\
\hline Urease & - & - \\
\hline Indole & - & - \\
\hline VP & - & - \\
\hline Nitrate reduced & + & + \\
\hline Casein hydrolysis & $\mathrm{x}$ & + \\
\hline Starch hydrolysis & + & + \\
\hline Oxidase & + & + \\
\hline Catalase & + & + \\
\hline $\mathrm{H} 2 \mathrm{~S}$ & - & - \\
\hline
\end{tabular}

Note: +: positive; - : negative; $\mathrm{x}$ : no data available; T: terminal; ST: sub-terminal; E: ellipsoidal 


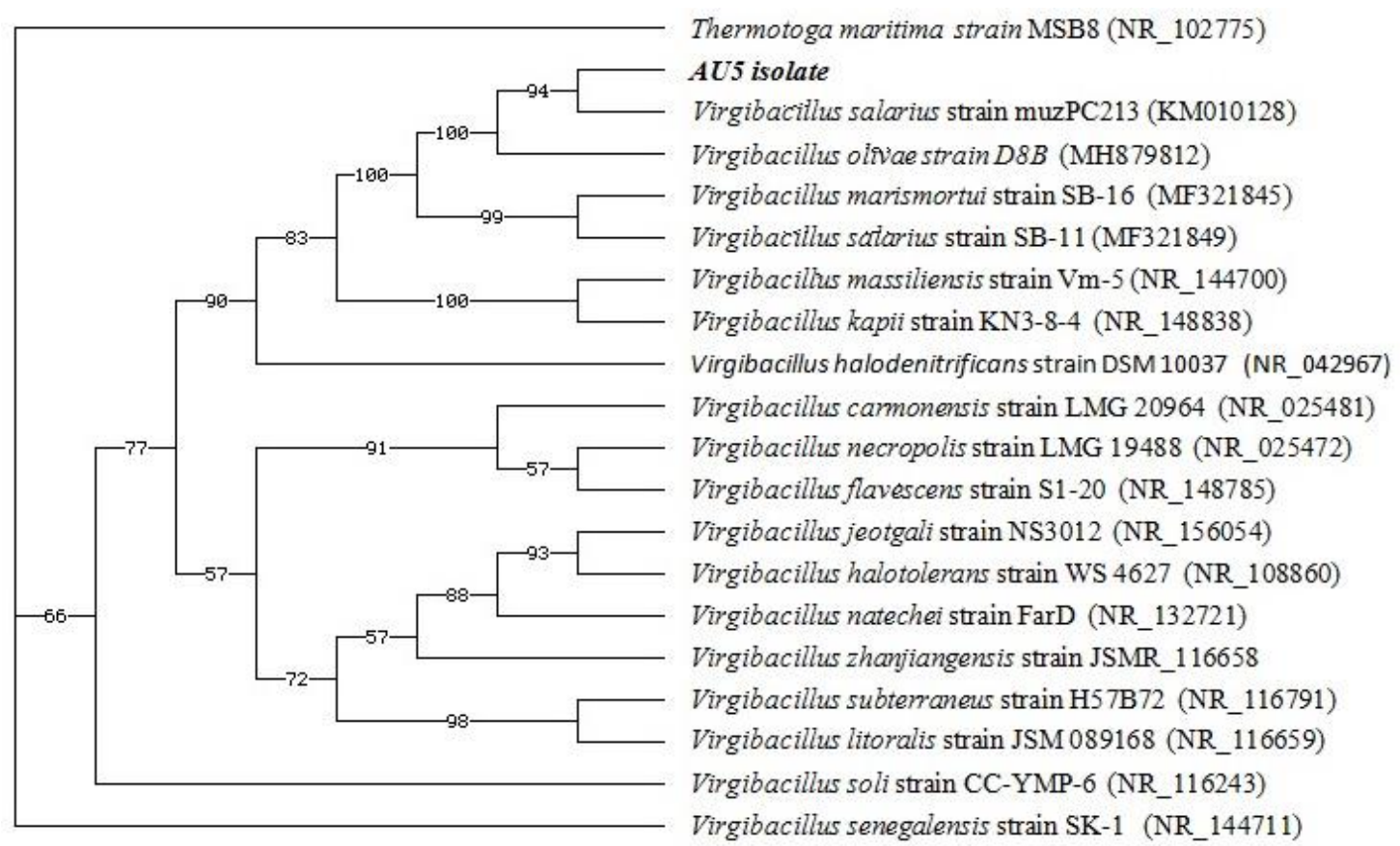

Figure 3. The phylogenetic tree was constructed by the NJ method with partial 16S rDNA sequences showing the position of the antagonistic bacteria (AU5) among members of the genus Virgibacillus and related taxa. Bootstrap values (expressed as percentages of 1,000 replications) are shown at major branching points. Thermotoga maritima strain MSB8 was used as an out-group

Table 3. Blast analyses of AU5 antagonistic property

\begin{tabular}{lclcc}
\hline Isolate & Acc. no. & $\begin{array}{c}\text { Closely } \\
\text { related }\end{array}$ & $\begin{array}{c}\text { GenBank } \\
\text { ID }\end{array}$ & $\begin{array}{c}\text { \% } \\
\text { similarity }\end{array}$ \\
\hline AU5 & LC461005 & $\begin{array}{l}\text { Virgibacillus } \\
\text { salarius } \\
\text { strain } \\
\text { muzPC213 }\end{array}$ & KM010128 & 99 \\
\hline
\end{tabular}

The similarity characters between AU5 isolate and Virgibacillus references was $84 \%$. Based on the morphological, physiological, and biochemical identification, the AU5 isolate was confirmed as Virgibacillus sp. Baron (1996) stated that strains of a given species might cluster at a $90 \%$ similarity level, species within a given genus may cluster at the 70 percent level, and different genera in the same family may cluster at the 50 percent or lower level.

\section{Molecular identification}

The results of the $16 \mathrm{~S}$ rDNA sequence antipathogenic AWS bacterial isolates AU5 showed that this isolate had a close relationship with Virgibacillus salarius strain muzPC213 (99\%) (Table 3). To clarify the phylogenetic proximity Virgibacillus and AU5 isolate, 16S rRNA gene sequences from the strains presented here were aligned to construct a phylogenetic tree. The phylogenetic analysis showed that the AU5 isolate was constant close to $V$. salarius strain muzPC213 (Figure 3 ).

In the marine environment, members of the family Bacillaceae (Bacillus, Virgibacillus, Oceanobacillus) known for the production of metabolites with antimicrobial and antifungal properties (Kurata et al., 2017). However, there was a lack of information regarding genus Virgibacillus that produce antimicrobial substances. Wijayanti et al. (2018) reported the V. salarius isolated from coral acroporid that has antipathogenic property against Black Band Disease. Kanagasabhapathy et al. (2005) reported that $V$. pantothenticus isolated from a marine sponge could inhibit the bacterial fouling. While Essghaier et al. (2014) reported that V. marismortui strain M3-23 have potential antimicrobial property against fungal disease by destroying of mycelial growth of Botrytis cinerea. Efforts to control coral diseases with bacteriophage have been made successfully under laboratory conditions (Efrony et al. 2007; Efrony et al. 2009; Atad et al. 2012; Cohen et al. 2009). The finding of this study showed that Virgibacillus species have special characteristics that make AU5 isolate good candidate as biological control agents against AWS disease. 


\section{ACKNOWLEDGEMENTS}

This study was supported by a grant from non-APBN DIPA SUKPA LPPM, Diponegoro University, Semarang, Indonesia under RPI scheme on the fiscal year 2016.

\section{REFERENCES}

Aronson RB, Precht WF. 2001. White-band disease and the changing face of Caribbean coral reefs. Hydrobiologia 460 (1): 25-38

Atad, I., A. Zvuloni, Y. Loya, E. Rosenberg, 2012. Phage therapy of the white plague-like disease of Favia favus in the Red Sea. Coral Reefs 31 (3): 665-670

Baker AC, Glynn' PW, Riegl B. 2008. Climate change and coral reef bleaching: An ecological assessment of long-term impacts, recovery trends, and future outlook. Estuar Coast Shelf Sci 80 (4): 435-471

Baron EJ. 1996. Classification. In: Baron S (ed.). Medical Microbiology. 4th ed. University of Texas Medical Branch at Galveston, Galveston, TX.

Baskett ML, Gaines SD, Nisbet RM. 2009. Symbiont diversity may help coral reefs survive moderate climate change. Ecol Appl 19 (1): 3-17.

Bruno JF, Selig ER, Casey KS, Page CA, Willis BL, Harvell CD, Sweatman H, Melendy AM. 2007. Thermal stress and coral cover as drivers of coral disease outbreaks. PLoS Biol 5 (6): e124. DOI 10.1371/journal.pbio.0050124

Campbell SJ, Kartawijaya T, Yulianto I, Prasetia R, Clifton J. 2013. Comanagement approaches and incentives improve managemen effectiveness in the Karimunjawa National Park, Indonesia. Mar Pol 41: 72-79.

Casey JM, Ainsworth TD, Choat JH, Connolly SR. 2014. Farming behavior of reef fishes increases the prevalence of coral disease associated microbes and black band disease. Proc. R. Soc. B 281: 20141032. DOI: 10.1098/rspb.2014.1032

Cohen Y, Pollock FJ, Rosenberg E, Bourne DG. 2013. Phage therapy treatment of the coral pathogen Vibrio coralliilyticus. Microbiol. Open 2 (1): 64-74.

Efrony R, Atad I, Rosenberg E. 2009. Phage therapy of coral white plague disease: properties of phage BA3. Curr Microbiol. 58 (2): 139-145

Efrony R, Loya Y, Bacharach E, Rosenberg E. 2007. Phage therapy of coral disease. Coral Reefs 26: 7-13.

Elkahoui S, Djébali N, Karkouch I, Ibrahim HA, Kalai L, Bachkouel S, Tabbene O. Limam, F. 2014. Mass Spectrometry Identification of Antifungal Lipopeptides from Bacillus sp. BCLRB2 Against Rhizoctonia Solani and Sclerotinia sclerotiorum. Appl. Biochem. Microbiol. 50 (2): 161-165.

Essghaier B, Dhieb C, Rebib H, Ayari S, Boudabous ARA, et al. (2014) Antimicrobial Behavior of Intracellular Proteins from Two Moderately Halophilic Bacteria: Strain J31 of Terribacillus halophilus and Strain M3-23 of Virgibacillus marismortui. J Plant Pathol Microb 5: 214.

Green EP, Bruckner AW. 2000. The significance of coral disease epizootiology for coral reef conservation. Biol Conserv 96 (3): $347-$ 361.

Heyndrickx M, Lebbe L, Kersters K, De Vos P, Forsyth G, Logan NA. 1998. Bacillus pantothenic (Proom and Knight 1950). An amended description of Virgibacillus pantothenticus. Intl J Syst Bacteriol 48: 99-106.

Kanagasabhapathy, M, Sasaki, H, Nakajima, K, Nagata, K, Nagata, S 2005. Inhibitory activities of surface-associated bacteria isolated from the marine sponge Pseudoceratina purpurea. Microb. Environ. 20, $178 \mathrm{e} 185$.

Kesarcodi-Watson A, Kaspar H, Lategan MJ, Gibson L. 2008. Probiotics in aquaculture: The need, principles, and mechanisms of action and screening processes. Aquaculture 274: 1-14

Komyakova V, Jones GP, Munday PL. 2018. Strong effects of coral species on the diversity and structure of reef fish communities: A multi-scale analysis. PLoS ONE 13 (8): e0202206. DOI: 10.1371/journal.pone.0202206.

Kurata, A., Y. Yamaura, T. Tanaka, C. Kato, K.Nakasone, N. Kishimoto, 2017. Antifungal peptidic compound from the deep-sea bacterium Aneurinibacillus sp. YR247. World J Microbiol Biotechnol 33 (4): 73.
Miller J, Muller E, Rogers C, Waara R, Atkinson A, Whelan KRT, Patterson M, Witche B. 2009. Coral disease following massive bleaching in 2005 causes $60 \%$ decline in coral cover on reefs in the US Virgin Islands. Coral Reefs (2009) 28: 925-937.

Nissimov J, Rosenberg E, Munn CB. 2009. Antimicrobial properties of resident coral mucus bacteria of Oculina patagonica, FEMS Microbiol. Lett. 292 (2): 210-215. DOI: 10.1111/j.15746968.2009.01490.x

Radjasa OK, Salasia SIO, Sabdono A, Weise J, Imhoff JF, Lammler C, Risk MJ. 2007. Antibacterial activity of marine bacterium Pseudomonas sp. associated with soft coral Sinularia polydactyla against Streptococcus equi subsp. zooepidemicus. Intl J Pharmacol 3: 170-174.

Raymundo LJ, Couch CS, Harvell CD. 2008. Coral disease handbook guidelines for assessment, monitoring and management. Currie Communications, Melbourne.

Reller LB, Weinstein M, Jorgensen JH, Ferraro MJ. 2009. Antimicrobial susceptibility testing: a review of general principles and contemporary practices. Clin Infect Dis 49 (11) : 1749-1755.

Reysenbach AL, Giver LG, Wickham GS, Pace NR (1992) Differential amplification of rRNA genes by polymerase chain reaction. Appl. Environ. Microbiol. 58: 3417-3418.

Richards ZT, Day JC. 2018. Biodiversity of the Great Barrier Reef-how adequately is it protected?. Peer J 6: e4747. DOI: 10.7717/peerj.4747.

Ritchie KB. 2006. Regulation of microbial populations by coral surface mucus and mucus-associated bacteria. Mar Ecol Prog Ser 322: 1-14.

Roff G, Mumby PJ. 2012. Global disparity in the resilience of coral reefs. Trends Ecol Evol. 27 (7): 404-13

Roff G, Hoegh-Guldberg O, Fine M. 2006. Intra-colonial response to Acroporid "white syndrome" lesions in tabular Acropora spp. (Scleractinia). Coral Reefs 25 (2): 255-264.

Rogers CS. 2013. Coral Reef Resilience through Biodiversity. ISRN Oceanography 2013: ID 739034. DOI: 10.5402/2013/739034.

Rypien KL, Ward JR, Azam F. 2009. Antagonistic interactions among coral-associated bacteria. Environ. Microbiol. 12 (1): 28-39.

Sabdono A, Radjasa OK, Wijayanti DP. 2019. Early Assessment of Shipping Route and Coral Cover as Drivers of Acroporid White Syndrome Outbreak in Karimunjawa, Java Sea, Indonesia. Diponegoro University, Semarang.

Sabdono A, Radjasa OK. 2008. Phylogenetic diversity of organophosphorous pesticide-degrading coral bacteria from MidWest Coast of Indonesia. Biotechnol. 7 (4): 694-701. DOI: 10.3923/biotech.2008.694.701

Shnit-Orland M, Kushmaro A. 2009. Coral mucus-associated bacteria: a possible first line of defense. FEMS Microbiol. Ecol. 67: 371-380.

Susanto H, Taufikurrahman I, van Balen S. 2014. Waders of Karimunjawa National Park, Central Java, Indonesia. Stilt, 66, 1-9.

Sussman M, Willis BL, Victor S, Bourne DG. 2008. Coral Pathogens Identified for White Syndrome (WS) Epizootics in the Indo-Pacific. PLoS One 3 (6): e2393. DOI: 10.1371/journal.pone.0002393.

Teplitski M, Ritchie K. 2009. How feasible is the biological control of coral diseases? Trends Ecol Evol 24: 378-385. DOI: 10.1016/J.Tree.2009.02.008

Thompson JD, Gibson TJ, Plewniak F, Jeanmougi F, Higgins DG. 1997. The Clustal X-Window interface: Flexible strategies for multiple alignments through sequence alignment aided by quality analysis tools. Nucl. Acids Res. 25: 4876-4882.

Weisburg WG, Barns SM, Pelletier DA, Lane DJ. 1991. 16S ribosomal DNA amplification for phylogenetic study. J of Bacteriol 173: 697703.

Wijayanti DP, Sabdono A, Widyananto PA, Dirgantara D, Hidaka M. 2018. Bacterial symbionts of acroporid corals: Antipathogenic potency against Black Band Disease. Biodiversitas 19 (4): 1235-1242.

Willis BL, Page, CA, Dinsdale EA. 2004. Coral disease on the Great Barrier Reef. In: Rosenberg E, Loya Y, editors. Coral health and disease. Springer-Verlag, Berlin.

Yamashiro H, Fukuda M, Fukami H. 2016. Outbreak of the white syndrome in Acropora spp., temperate region of Japan. Mar. Biodiv. 46: 321-322.

Yoon J-H, Oh T-K, Park Y-H. 2004. Transfer of Bacillus halodenitrificans Denariaz et al. 1989 to the genus Virgibacillus as Virgibacillus halodenitrificans comb. nov. Intl J Syst Evol Microbiol. 54: 2163-2167. 